\section{Soil Properties and Nutrient Availability in Tarweed Communities of Central Washington ${ }^{1}$}

\author{
ARTHUR R. TIEDEMANN2
}

Range Scientist, Pacific Northwest Forest and Range Experiment Station, 3 Forest Service, U.S. Department of Agriculture, Wenatchee, Washington

\section{Highlight}

Comparison of soil nutrient levels and certain soil physical properties between tarweed communities and adjacent stable, productive needlegrass communities indicated a lower nutrient capital of $\mathbf{N}, S$, and exchangeable $M n$ and poorer physical condition in the tarweed communities. Pot studies with mountain brome and orchard grass revealed low availability of $N, S$, and $P$ in soils from tarweed communities and suggest a need to amend native soil nutrients with these elements.

High elevation grasslands on basalt-capped plateaus dominated by Columbia needlegrass (Stipa columbiana Macoun.) are important summer range for livestock and wildlife in north central Washington. These plateaus are also vital sources of water.

A prevalent problem on many of these areas is a series of abrupt breaks in the grassland vegetation, resulting in a mosaic of barren areas dominated by cluster tarweed (Madia glomerata Hook.) (Fig. 1). These breaks are characterized by a 15- to $20-\mathrm{cm}$ lower soil surface, a high percentage of bare soil, an abrupt ecotone from a community dominated by perennial grasses and forbs to one dominated by annual forbs and active frost heaving. Topography of this nature is referred to locally as biscuit-scab or biscuit-swale.

According to Kaatz (1959), patterned ground of the type described covers hundreds of square miles of central Washington and appears to have resulted from intensive frost action associated with a periglacial climate. Daubenmire (1970) describes abrupt vegetation discontinuities which coincide with loessial-lithosolic soil contacts. However, he could find no consistent differences in soil characteristics that would explain the vegetation discontinuities.

Revegetation studies have shown that competition for moisture by cluster tarweed and frost heaving of new grass seedlings are the primary obstacles to revegetation of barren areas (Stevenson, 1950; Hull and Cox, 1968). These authors con-

\footnotetext{
${ }^{1}$ Received October 15, 1971.

2 The assistance of Tom D. Anderson, project chemist, in the collection of field and greenhouse data and analysis of soils is gratefully acknowledged by the author.

${ }^{3}$ Central headquarters located in Portland, Oregon.
}

cluded that cultivation and seeding in the spring resulted in the best grass stands. However, Hull and Cox found that this procedure was impractical on heavy soils and alternatively advised spraying annual weeds with 2,4-D in the spring, drilling grass seed in the fall, and respraying weeds the following spring. Although Hull and Cox tested various fertilizer treatments, they apparently did not test them in conjunction with the weed control and drilling schedules, and none were judged successful.

The abrupt drop in soil surface between needlegrass and tarweed communities indicates that much of the topsoil is either missing or has never developed. Because of this, there is a possibility that soil nutrients are a limiting factor in the tarweed community. To insure successful revegetation of these tarweed communities with perennial grasses, it is necessary to acquire a knowledge of the native nutrient capital and nutrient availability of the soils of the tarweed communities.

Using characteristics of the soil from needlegrass communities as a reference, this study evaluates the nutrient capital and nutrient availability of soils from adjacent tarweed communities. At the same time, comparison of physical and chemical soil properties of the two communities will be used to indicate the favorability of the tarweed community for germination and establishment of seeded perennial grasses and forbs.

\section{The Study Area}

Table Mountain, a basalt-capped plateau at an elevation of $1,850 \mathrm{~m}$ near Ellensburg, Washington, was the study area. The mosaic pattern of tarweed communities with islands of needlegrass communities is prominent in this area, occurring as open parks among stands of subalpine fir (Abies lasiocarpa (Hook.) Nutt.).

Vegetation of the needlegrass communities consists primarily of perennial grasses, sedges, and forbs such as Columbia needlegrass, tufted hairgrass (Deschampsia caespitosa (L.) Beauv.), Idaho fescue (Festuca idahoensis Elmer), Raynolds sedge (Carex raynoldsi Dewey), mountain dandelion (Agoseris glauca (T. and G.) Jeps.), lambstongue groundsel (Senecio integerrimus (Greenm.) Cronq.), butterweed groundsel (S. serra Hook.), and aster (Aster foliaceus (D. C. Eat.) Gray). In the tarweed communities, annual plants such as cluster tarweed, Sawatch knotweed (Polygonum sawatchense Small), Kellogg knotweed ( $P$. kelloggi Greene), woodlandstar (Lithophragma bulbifera Rydb.), collinsia (Collinsia parviflora (Pursh.) Piper), and cryptantha (Cryptantha torreyana (Gray) Greene) are prominent. Three common perennial species in the tarweed community are bottlebrush squirreltail (Sitanion hystrix (Nutt.) J. G. Smith), lupine (Lupinus wyethi Wats.), and phacelia (Phacelia hastata (Torr.) Cronq.).

The soil, developed from basalt parent material, is a loam of the Anatone series. 4 Anatone soils have a reddish-

\footnotetext{
${ }^{4}$ Unpublished soil survey report for Chelan County, Washington, U.S. Dep. Agr. Soil Cons. Serv.
} 


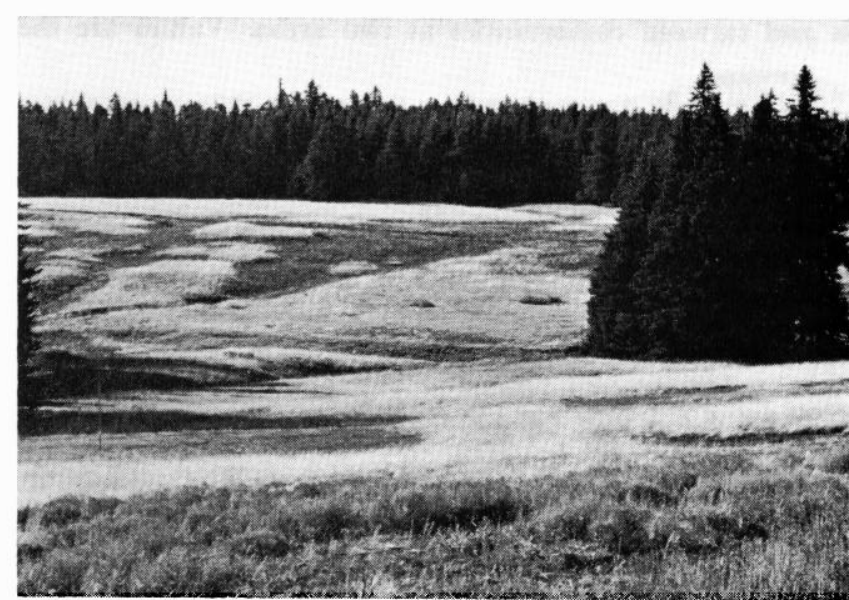

Fig. 1. Mosaic of needlegrass and tarweed communities on Table Mountain.

brown, extremely stony $\mathrm{Al}$ horizon and a reddish-brown, very gravelly, and cobbly silt loam $B$ horizon. Depth ranges from 25 to $50 \mathrm{~cm}$. These soils are well drained with moderate permeability and medium to rapid runoff.

Total annual precipitation is about $90 \mathrm{~cm}$, occurring mostly as snow, and mean annual temperature is approximately 2 C (Berndt and Fowler, 1969).

\section{Methods}

Two separate areas were selected for study. The first, referred to as the upland area, is on a gently sloping, southeast-facing hillside near the top of a ridge. The other, designated the lowland area, is $400 \mathrm{~m}$ away at the foot of a slope facing generally southwest. Three separate and distinct needlegrass and tarweed communities in each area were selected for sampling. Soil cores and loose samples of soil were collected at depths of 0 to $7.5 \mathrm{~cm}$ and 7.5 to $15 \mathrm{~cm}$ at three random locations in each community.

Properties measured included: bulk density, soil texture, $\mathrm{pH}$, organic matter, and total $\mathrm{P}$ (Black et al., 1965a and 1965b); total N (Keeney and Bremner, 1967); total K (Belt, 1967); total S (Tiedemann and Anderson, 1971); cation exchange capacity (Chapman and Pratt, 1961; Ballentine and Gregg, 1947); and exchangeable $\mathrm{Ca}, \mathrm{Mg}, \mathrm{Mn}$, $\mathrm{Na}$, and $\mathrm{K}$ by atomic absorption spectroscopy (Robinson, 1966). All determinations were made in duplicate. Data were evaluated using analyses of variance of a split-plot design with areas and communities as factors of the whole plot units and depths as a split-plot factor. Whole plot units are arranged completely at random.

To evaluate the availability of $\mathrm{N}, \mathrm{P}, \mathrm{K}$, and $\mathrm{S}$ in soil from the two communities, a pot test was conducted using orchard grass (Dactylis glomerata L.) and mountain brome (Bromus carinatus Hook. and Arn.).

Soil was collected from each community at each area to a depth of $15 \mathrm{~cm}$, screened in the field through a $1 / 2-\mathrm{cm}$ screen, brought to the laboratory, and air-dried.

Plants of the two species were grown from seed in separate pots containing $1,000 \mathrm{~g}$ of soil to which the following nutrient treatments were added:
(1) $\mathrm{N}_{0} \mathrm{P}_{0} \mathrm{~K}_{0} \mathrm{~S}_{0}$
(2) NPKS
(3) $\mathrm{N}_{0} \mathrm{PKS}$

Check

Full nutrient treatment

No nitrogen
(4) $\mathrm{NP}_{0} \mathrm{KS}$

(5) $\mathrm{NPK}_{0} \mathrm{~S}$

(6) $\mathrm{NPKS}_{0}$

No phosphorus

No potassium

No sulphur

Nutrients were applied at rates equivalent to $224 \mathrm{~kg} / \mathrm{ha}$ of $\mathrm{N}$ as ammonium nitrate $(44.6 \mathrm{mg} / \mathrm{kg}=100 \mathrm{~kg} / \mathrm{ha}), 336$ $\mathrm{kg} / \mathrm{ha}$ of $\mathrm{P}_{2} \mathrm{O}_{5}$ as monosodium phosphate, $112 \mathrm{~kg} / \mathrm{ha}$ of $\mathrm{K}$ as potassium chloride, and $112 \mathrm{~kg} / \mathrm{ha}$ of $\mathrm{S}$ as calcium sulphate. Plants were grown in a greenhouse under 12-hour photoperiod and night and day temperatures of 18 and and $24 \mathrm{C}$, respectively. Distilled water was added to the pots to replace evapotranspiration losses.

All foliar material was harvested after 16 weeks, ovendried, and weighed. Relative yield was used as an indication of the availability of each nutrient tested. The relative yield of a nutrient is an expression of the capacity of a soil to supply that nutrient under the experimental conditions employed (Jenny et al., 1950; Klemmedson and Jenny, 1965). It is the ratio of the yield without the nutrient to the yield with the full nutrient treatment. For example, the relative yield for

$$
\mathrm{N}(\mathrm{RYN})=\frac{\text { yield in grams with } \mathrm{N}_{0} \mathrm{PKS}}{\text { yield in grams with NPKS }} \times 100
$$

The higher the relative yield, the greater the availability of a particular nutrient to a given plant species.

Data from the pot test were not analyzed statistically because field replication was not carried through to the greenhouse.

\section{Results}

\section{Soil Tests}

Of the physical and chemical properties measured, only bulk density, organic matter, total $\mathrm{N}$, total S, and exchangeable Mn displayed significant departures between needlegrass and tarweed soils (Table 1). However, these properties indicated that soil from tarweed communities had a less favorable physical condition and a lower nutrient capital than needlegrass soil, and that the upland area was more fertile than the lowland area.

Average bulk density in needlegrass soil was $0.87 \mathrm{~g} / \mathrm{cm}^{3}$ compared with $1.06 \mathrm{~g} / \mathrm{cm}^{3}$ in tarweed soil-a highly significant difference. Although no significant difference between depths was observed, there was a significant depths $\times$ communities interaction. In the tarweed communities, bulk density decreased from 1.11 to $1.02 \mathrm{~g} / \mathrm{cm}^{3}$ between the 0 to 7.5 -cm and 7.5 - to 15 -cm depths, whereas in the needlegrass communities bulk density increased between those depths from 0.85 to $0.88 \mathrm{~g} / \mathrm{cm}^{3}$ (Table 2).

Average organic matter content in soil from the needlegrass communities was more than twice as great as in tarweed communities $(6.7 \%$ compared with $3.1 \%$ ). This difference is highly significant. Areas did not differ significantly in their content of organic matter; but the areas $\times$ communities interaction was significant, reflecting a difference in organic matter content of $4.8 \%$ between communities at the upland area compared with a differ- 
Table 1. Physical and chemical soil properties of needlegrass and tarweed communities at two areas. Values are the average of the 0- to 7.5- and 7.5- to $15.0-\mathrm{cm}$ depths.

\begin{tabular}{|c|c|c|c|c|c|c|}
\hline \multirow[b]{2}{*}{ Property } & \multicolumn{2}{|c|}{ Upland } & \multicolumn{2}{|c|}{ Lowland } & \multirow{2}{*}{$\begin{array}{l}\text { F-test } \\
\text { areas }\end{array}$} & \multirow{2}{*}{$\begin{array}{c}\text { F-test } \\
\text { communities }\end{array}$} \\
\hline & Needlegrass & Tarweed & Needlegrass & Tarweed & & \\
\hline $\mathrm{pH}$ & 5.4 & 5.6 & 5.7 & 5.7 & NS & NS \\
\hline Bulk density $1\left(\mathrm{~g} / \mathrm{cm}^{3}\right)$ & 0.84 & 1.08 & 0.88 & 1.04 & NS & ** \\
\hline Sand $(\%)$ & 34.0 & 40.0 & 37.0 & 41.0 & NS & NS \\
\hline Silt $(\%)$ & 42.0 & 43.0 & 40.0 & 39.0 & NS & NS \\
\hline Clay $(\%)$ & 24.0 & 17.0 & 23.0 & 20.0 & NS & NS \\
\hline Organic matter $(\%)$ & 7.7 & 2.9 & 5.7 & 3.3 & NS & ** \\
\hline Total N (\%) & 0.40 & 0.16 & 0.28 & 0.18 & * & $* *$ \\
\hline Total P (\%) & 0.12 & 0.12 & 0.15 & 0.13 & $*$ & NS \\
\hline Total K (\%) & 0.64 & 0.51 & 0.66 & 0.64 & NS & NS \\
\hline Total S $(\%)$ & 0.042 & 0.019 & 0.031 & 0.024 & NS & $* *$ \\
\hline \multicolumn{7}{|l|}{ Cation exchange } \\
\hline capacity $(\mathrm{me} / 100 \mathrm{~g})$ & 41.9 & 40.7 & 41.6 & 34.6 & NS & NS \\
\hline Exchangeable $\mathrm{K}(\mathrm{me} / \mathrm{l00} \mathrm{g})$ & 1.92 & 0.91 & 1.30 & 0.79 & NS & NS \\
\hline Exchangeable $\mathrm{Mn}(\mathrm{me} / 100 \mathrm{~g}$ ) & 0.094 & 0.042 & 0.076 & 0.051 & NS & $* *$ \\
\hline Exchangeable $\mathrm{Na}$ (me $100 \mathrm{~g}$ ) & 0.19 & 0.17 & 0.20 & 0.20 & NS & NS \\
\hline Exchangeable $\mathrm{Mg}(\mathrm{md} / 100 \mathrm{~g})$ & 1.91 & 2.54 & 2.09 & 3.24 & NS & NS \\
\hline Exchangeable $\mathrm{Ca}$ (me $/ 100 \mathrm{~g}$ ) & 11.93 & 13.43 & 11.44 & 11.43 & NS & NS \\
\hline
\end{tabular}

${ }^{1}$ Gravel percentage was not taken into account.

* Significant at the $5 \%$ level.

** Significant at the $1 \%$ level.

NS $=$ Not significant.

ence of only $2.4 \%$ at the lowland area. Organic matter declined significantly $(P=0.01)$ between depths, but most of the difference occurred in the needlegrass communities-a response signalled by a highly significant depths $\times$ communities interaction. In the needlegrass communities, organic matter decreased from 7.5 to $5.9 \%$ between the 0 to 7.5- and 7.5- to 15-cm depths, whereas in the tarweed communities it decreased only from 3.2 to $3.0 \%$.

Total N, total S, and exchangeable Mn were the only soil nutrients that differed significantly be-

Table 2. Comparison of physical and chemical properties between the 0- to 7.5- and 7.5- to 15.0-cm depths in needlegrass and tarweed communities. Values are the average of the upland and lowland areas.

\begin{tabular}{|c|c|c|c|c|c|}
\hline \multirow[b]{2}{*}{ Property } & \multicolumn{2}{|c|}{ Needlegrass } & \multicolumn{2}{|c|}{ Tarweed } & \multirow{2}{*}{$\begin{array}{c}\text { F-test } \\
\text { depths }\end{array}$} \\
\hline & 0 to $7.5 \mathrm{~cm}$ & 7.5 to $15.0 \mathrm{~cm}$ & 0 to $7.5 \mathrm{~cm}$ & 7.5 to $15.0 \mathrm{~cm}$ & \\
\hline $\mathrm{pH}$ & 5.5 & 5.6 & 5.7 & 5.6 & NS \\
\hline Bulk density $1\left(\mathrm{~g} / \mathrm{cm}^{3}\right)$ & 0.85 & 0.88 & 1.11 & 1.02 & NS \\
\hline Sand $(\%)$ & $36.0^{1}$ & 35.0 & 40.0 & 41.0 & NS \\
\hline Silt $(\%)$ & 41.0 & 40.0 & 42.0 & 40.0 & NS \\
\hline Clay $(\%)$ & 23.0 & 25.0 & 18.0 & 19.0 & NS \\
\hline Organic matter (\%) & 7.5 & 5.9 & 3.2 & 3.0 & ** \\
\hline Total N (\%) & 0.36 & 0.32 & 0.18 & 0.17 & * \\
\hline Total P (\%) & 0.13 & 0.14 & 0.12 & 0.13 & NS \\
\hline Total K (\%) & 0.65 & 0.65 & 0.58 & 0.57 & NS \\
\hline Total S (\%) & 0.041 & 0.038 & 0.023 & 0.023 & NS \\
\hline \multicolumn{6}{|l|}{ Cation exchange } \\
\hline capacity (me/100 g) & 41.8 & 41.8 & 38.2 & 37.1 & NS \\
\hline Exchangeable $\mathrm{K}$ (me/100 g) & 1.68 & 1.54 & 0.88 & 0.82 & NS \\
\hline Exchangeable $\mathrm{Mn}$ (me/l00 g) & 0.112 & 0.057 & 0.057 & 0.036 & $* *$ \\
\hline Exchangeable $\mathrm{Na}$ (me/100 g) & 0.19 & 0.20 & 0.18 & 0.18 & NS \\
\hline Exchangeable $\mathrm{Mg}(\mathrm{me} / 100 \mathrm{~g})$ & 2.00 & 2.00 & 2.46 & 2.41 & NS \\
\hline Exchangeable $\mathrm{Ca}$ (me/100 g) & 11.50 & 11.88 & 12.46 & 12.40 & NS \\
\hline
\end{tabular}

${ }^{1}$ Gravel percentage was not taken into account.

* Significant at the $5 \%$ level.

** Significant at the $1 \%$ level.

NS $=$ Not significant. 


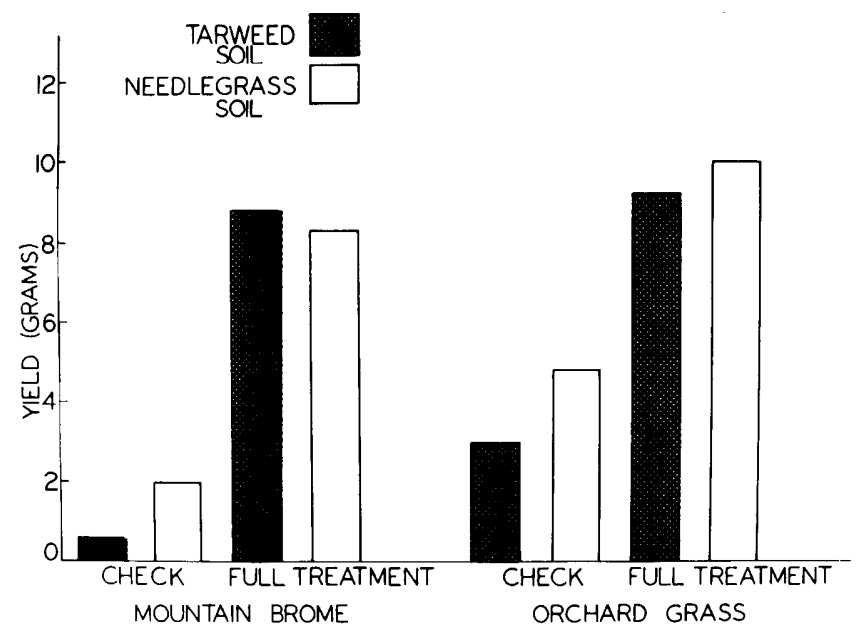

Fig. 2. Yield of mountain brome and orchard grass with the check and full nutrient treatments.

tween needlegrass and tarweed communities. Average total $\mathbf{N}$ was twice as great in needlegrass soil $(0.34 \%)$ as in tarweed soil $(0.17 \%)$. This difference is highly significant. Also, total $\mathrm{N}$ was significantly higher $(P=0.01)$ at the upland than lowland area, and the areas $\times$ communities interaction was highly significant. Total $\mathrm{N}$ declined significantly between the 0 - to 7.5- and 7.5- to 15-cm depths, but most of the difference between depths was confined to the needlegrass communities.

Soil from the needlegrass communities contained significantly more total $\mathrm{S}$ than soil from tarweed communities $(0.036 \%$ compared with $0.022 \%$ ). However, in contrast to total $\mathrm{N}$, there was no significant difference in total $S$ between areas, the areas $\times$ communities interaction was not significant, and there was no change with depth.

Exchangeable Mn was nearly twice as great in needlegrass soil $(0.085 \mathrm{me} / 100 \mathrm{~g})$ as in tarweed soil $(0.046 \mathrm{me} / 100 \mathrm{~g})$. Exchangeable $\mathrm{Mn}$ declined significantly with depth $(P=0.01)$, and the depths $\times$ communities interaction was highly significant.

\section{Pot Tests}

Absolute yields of mountain brome and orchard grass supported results of soil tests, indicating that soils from needlegrass communities were more fertile than soils from tarweed communities and that the upland area had a higher nutrient capital than the lowland area. Total yield of both test species was higher in needlegrass soil than tarweed and higher at the upland area than lowland.

Yield of both species with the check treatment was greater in needlegrass soil than in tarweed soil (Fig. 2), but there was no difference between soils for full nutrient treatment yields. Mountain brome yield in tarweed soil with the full nutrient treatment was 14 times greater than check yield. In the
Table 3. Relative yields (\%) of four nutrients in soil from needlegrass and tarweed communities with orchard grass and mountain brome.

\begin{tabular}{|c|c|c|c|c|}
\hline \multirow[b]{2}{*}{ Nutrient } & \multicolumn{2}{|c|}{ Upland area } & \multicolumn{2}{|c|}{ Lowland area } \\
\hline & Needlegrass & Tarweed & Needlegrass & Tarweed \\
\hline \multicolumn{5}{|c|}{ Orchard grass } \\
\hline $\mathbf{N}$ & 56 & 39 & 66 & 34 \\
\hline$P$ & 48 & 60 & 77 & 73 \\
\hline $\mathbf{K}$ & 93 & 96 & 100 & 93 \\
\hline$S$ & 61 & 54 & 74 & 53 \\
\hline \multicolumn{5}{|c|}{ Mountain brome } \\
\hline $\mathbf{N}$ & 56 & 8 & 22 & 15 \\
\hline $\mathbf{P}$ & 47 & 62 & 60 & 29 \\
\hline $\mathbf{K}$ & 115 & 103 & 105 & 106 \\
\hline $\mathrm{S}$ & 66 & 51 & 57 & 29 \\
\hline
\end{tabular}

needlegrass soil, the full nutrient treatment yield was four times greater than the check yield. With orchard grass the increase between the check and full treatment yield was three times in tarweed soil and two times in needlegrass soil.

Relative yields showed that N, S, and P were the nutrients primarily responsible for differences in check yields between needlegrass and tarweed soils (Table 3). Potassium was $100 \%$ available in soils from both communities.

Mountain brome appeared to be the more sensitive of the two species as an indicator of nutrient availability. At the upland area the relative yield of $\mathrm{N}$ for mountain brome was $56 \%$ in soil from the needlegrass community compared with $8 \%$ in soil from the tarweed community. Thus, $\mathrm{N}$ was seven times more available in needlegrass than in tarweed soil. Sulphur was only slightly more available in needlegrass soil $(66 \%)$ than in tarweed soil $(51 \%)$. Phosphorus, in contrast, was more available in tarweed soil. At the lowland area, the difference in availability of $\mathrm{N}$ for mountain brome narrowed between needlegrass soil and tarweed soil-22\% and $15 \%$, respectively. At the same time, the difference in relative yields for $P$ and $S$ between communities increased so that $P$ and $S$ were twice as available in needlegrass soil as in tarweed soil.

Relative yield differences between needlegrass and tarweed soils for orchard grass were not as pronounced as those for mountain brome. Nor did the test indicate a deficiency of $P$ in the lowland tarweed community as observed with mountain brome. Nitrogen was about two-thirds and onehalf respectively, as available in tarweed soil as in needlegrass soil at upland and lowland areas. Availability of $S$ was only slightly different in the two soils at the upland area but about two-thirds as available in tarweed soil as in needlegrass soil at the lowland area. 


\section{Discussion and Conclusions}

Establishment of the needlegrass community as a base for judging favorability of soil of the tarweed community for germination and establishment of seeded species appears justified on the basis of soil nutrient levels.

According to Jenny's guidelines (1930), the average level of total $\mathrm{N}$ in the needlegrass soil of $0.34 \%$ is at an upper limit for this site. Total phosphorus is also at the upper limit of the range observed in the northwest United States (0.09 to $0.13 \%)$, but total $\mathrm{K}$ is below the range reported for most soils of the western United States of 1.7 to $2.5 \%$ (Parker et al., 1946). Sulphur is in the middle of the range reported by Burns (1968) for most soils (0.01 to $0.06 \%$ ).

From the calculated $C: N: S$ ratio of $114: 9: 1$ in needlegrass soil, it appears that $\mathrm{N}$ is optimally available and that the $S$ level is high enough that $\mathrm{N}$ would be utilized efficiently (Black, 1968; Burns, 1968).

Despite the apparent favorability of the nutrient regime of needlegrass soil, relative yields of the four nutrients showed that only $\mathrm{K}$ was $100 \%$ available-and it was the only nutrient below the commonly observed level.

The contrasting availability of nutrients to mountain brome and orchard grass is probably a result of differential nutrient requirements of the two species, and an indication of the ability of each species to utilize the native nutrient capital of the soil. Orchard grass appears to have a lower nutrient requirement and greater ability to utilize the existing soil nutrients than mountain brome.

However, relative yields with mountain brome were a better reflection of differences in actual nutrient levels between needlegrass and tarweed communities and between upland and lowland areas than orchard grass. Moreover, the response of mountain brome suggests that a comparison of actual soil nutrient levels is not a true indication of nutrient availability. There were no apparent differences in the level of soil $P$ between communities, and yet $\mathbf{P}$ was two times more available to mountain brome in needlegrass soil than in tarweed soil at the lowland area. For N, the disparity between nutrient level differences and nutrient availability was even more pronounced. Total $\mathbf{N}$ was more than two times greater in needlegrass soil than in tarweed soil at the upland area-and seven times more available for mountain brome. Also, the relative yield of $22 \%$ in needlegrass soil for mountain brome was a reflection of the lower level of $\mathbf{N}$ at the lowland area.

The results indicate that there are severe deficiencies and low nutrient availability of $\mathrm{N}$ and $\mathrm{S}$ in tarweed communities of this area. In addition to the recommended procedures of Hull and Cox
(1968), revegetation efforts should include a fertilizer program to amend soil $\mathrm{N}$ at the upland area and $\mathrm{N}, \mathrm{P}$, and $\mathrm{S}$ at the lowland area.

Because of the differences in relative yields of $\mathrm{N}, \mathrm{P}$, and $\mathrm{S}$ between orchard grass and mountain brome in tarweed soil, and the fact that only $\mathrm{K}$ was $100 \%$ available in needlegrass soil, there appears to be a need to establish relative yield criteria for these nutrients in wildland soils using individual species to be seeded. Jenny et al. (1950) established such criteria for $\mathrm{N}$ and $\mathrm{P}$ using lettuce on agricultural soils of California. According to these workers, a relative yield of $\mathrm{N}$ of $30 \%$ or less in a pot test indicates a soil low in $\mathrm{N}$ which will give a field response for added $\mathrm{N}$. A relative yield above $50 \%$ indicates a high $\mathrm{N}$ supply with little chance for a field response. For $\mathrm{P}$, these relative yield levels are $20 \%$ and $30 \%$.

Since relative yields of the four nutrients with mountain brome and orchard grass were similar in needlegrass soil at the upland area, perhaps these values can be established as an upper limit for these two species in soil from stable, productive high elevation grasslands. Confirmation of this would require field tests to determine if a significant response to added nutrients would occur in needlegrass soil at the upland area.

Although the effect of higher bulk density and lower organic matter content on the microenvironment of tarweed soils was not measured, these two characteristics probably contribute to rapid heat exchange between the soil and atmosphere, rapid heat transfer within the soil, reduced infiltration, and rapid drying of the soil surface. All of these factors would likely have an adverse effect on seedling establishment in the late spring.

\section{Literature Cited}

Ballentine, R., and J. R. Gregg. 1947. Micro-kjeldahl determination of nitrogen. Anal. Chem. 19:281-283.

Belt, Charles Banks, Jr. 1967. Partial analysis of silicate rocks by atomic absorption. Anal. Chem. 39:676-678.

Berndt, H. W., AND W. B. Fowler. 1969. Rime and hoarfrost in upper-slope forests of eastern Washington. J. Forest. 67:92-95.

Black, Charles A. 1968. Soil-plant relationships. 2nd ed. John Wiley and Sons, Inc., New York. 792 p.

Black, C. A., D. D. Evans, J. L. White, and Others. 1965a. Methods of soil analysis. Part I, Agronomy No. 9, Amer. Soc. Agron. and Amer. Soc. Testing Mater., Madison, Wis. $770 \mathrm{p}$.

Black, C. A., D. D. Evans, J. L. White, and Others. 1965b. Methods of soil analysis. Part 2, Agronomy No. 9, Amer. Soc. Agron. and Amer. Soc. Testing Mater., Madison, Wis. 802 p.

Burns, George R. 1968. Oxidation of sulphur in soils. Sulphur Inst. Tech. Bull. No. 13. 41 p.

Chapman, Homer Dwight, and P. F. Pratt. 1961. 
Methods of analysis for soils, plants, and waters. Univ. Calif. Div. Agr. Sci. 309 p.

Daubenmire, R. 1970. Steppe vegetation of Washington. Wash. Agr. Exp. Sta., Tech. Bull. 62. 131 p.

Hull, A. C., JR., AND Hallie Cox. 1968. Spraying and seeding high elevation tarweed rangelands. J. Range Manage. 21:140-144.

JenNy, H. 1930. A study on the influences of climate upon the nitrogen and organic matter content of the soil. Mo. Agr. Exp. Sta. Res. Bull. 152. 66 p.

Jenny, H., J: Vlamis, and W. E. Martin. 1950. Greenhouse assay of fertility of California soils. Hilgardia 20: $1-8$.

KaAtz, Martin R. 1959. Patterned ground in central Washington: a preliminary report. Northwest Sci. 33: 145-156.

KeEney, D. R., ANd J. M. Bremner. 1967. Use of the
Coleman Model 29a analyzer for total nitrogen analysis of soils. Soil Sci. 104:358-363.

Klemmedson, James O., and Hans Jenny. 1965. Nitrogen availability in California soils in relation to precipitation and parent material. Soil Sci. 102:215-222.

Parker, F. W., J. R. Adams, K. G. Clark, and Others. 1946. Fertilizers and lime in the United States: resources, production, marketing, and use. U.S. Dep. Agr. Misc. Pub. 586. 94 p.

Robinson, James William. 1966. Atomic absorption spectroscopy. Marcel Dekker, Inc., New York. 204 p.

Stevenson, E. W. 1950 . Reseeding tarweed-infested ranges. USDA Forest Serv. Pac. Northwest Forest \& Range Exp. Sta. Res. Note 68. 6 p.

Tiedemann, Arthur R., and Tom D. Anderson. 1971. Rapid analysis of total sulphur in soils and plant material. Plant and Soil 35(1):197-200. 